Cox, W. A., T. Dellinger, R. Kiltie, B. Bankovich, and B. Tornwall. 2020. Factors associated with local and statewide population trends of the Florida Sandhill Crane (Antigone canadensis pratensis). Avian Conservation and Ecology 15(1):7. https://doi.org/10.5751/ACE-01519-150107 Copyright (C) 2020 by the author(s). Published here under license by the Resilience Alliance.

Research Paper

\title{
Factors associated with local and statewide population trends of the Florida Sandhill Crane (Antigone canadensis pratensis)
}

\author{
W Andrew Cox ${ }^{1}$, Timothy A. Dellinger ${ }^{1}$, Richard Kiltie ${ }^{1}$, Brittany Bankovich ${ }^{1}$ and Brett Tornwall $^{2}$ \\ ${ }^{1}$ Fish and Wildlife Research Institute, Florida Fish and Wildlife Conservation Commission, ${ }^{2}$ Children's Oncology Group \& Dept. \\ Of Biostatistics, Colleges of Medicine, Public Health \& Health Professions, University of Florida
}

\begin{abstract}
Breeding Bird Survey (BBS) data indicate that the Florida population of the nonmigratory Florida Sandhill Crane (Antigone canadensis pratensis) has been increasing for 50 years despite substantial habitat loss and a recent period of extended drought. We generated BBS route-specific population trends for 1966-2016 to identify locations in Florida that had experienced significant increases or declines to better understand the statewide population growth. We also assessed whether changes in land cover over time were correlated with local increases or decreases in the Sandhill Crane population. Finally, we explored how drought during the breeding season affected the number of cranes detected during the BBS and the number of young cranes detected in a fall post-reproductive survey we conducted during 1991-2016. Of the 42 BBS routes on which cranes were observed in $\geq 4$ years, populations increased on $17(40 \%)$ and declined on one (2\%), and no change was detected on $24(57 \%)$. Routes with positive population growth occurred throughout the breeding range, with one hot spot of growth occurring in the northwest region of central Florida. Change in five primary land cover types (grassland, wetland, scrub/successional, woodland, urban) during 1985-2016 did not predict changes in Sandhill Crane populations. Drought conditions during a prior year's breeding season were negatively correlated with BBS counts, and within-season drought conditions were negatively correlated with juvenile crane counts on the post-reproductive surveys. Productivity rates in all but the driest years were similar to those associated with stable or growing crane populations. Continued monitoring is warranted because the longevity of adult cranes could mask an impending population decline and because little is known about the cranes that reside in the suburban landscapes that make up an increasingly large proportion of Florida's landscapes.
\end{abstract}

\section{Facteurs liés à la tendance de population de la Grue du Canada de Floride (Antigone canadensis pratensis) aux échelles locale et de l'État}

RÉSUMÉ. Les données du Relevé des oiseaux nicheurs (BBS) indiquent que la population non-migratrice de la Grue du Canada de Floride (Antigone canadensis pratensis) augmente depuis 50 ans malgré les pertes considérables d'habitat et une récente période de sécheresse prolongée. Nous avons généré des tendances de population spécifiques aux routes BBS pour la période 1966-2016 afin d'identifier des sites où les populations ont augmenté ou diminué de façon importante en Floride, pour ultimement mieux comprendre le taux de croissance dans l'ensemble de cet État. Nous avons aussi évalué si les changements advenus sur le plan de l'occupation du sol étaient corrélés aux hausses ou aux baisses locales de la population de grues. Enfin, nous avons exploré de quelle façon les sécheresses survenant en saison de nidification influaient sur le nombre de grues détectées pendant le BBS et le nombre de jeunes grues détectées lors des relevés automnaux post-reproduction tenus en 1991-2016. Sur les 42 routes BBS dans lesquelles des grues ont été observées au moins 4 années, les effectifs ont augmenté dans 17 d'entre elles (40\%) et diminué dans une autre (2\%), tandis qu'aucun changement de population n'a été détecté dans 24 routes (57\%). Les routes montrant une croissance de population positive étaient réparties dans l'ensemble de l'aire de nidification, et un site particulier de croissance se trouvait dans la région nord-ouest du centre de la Floride. Les changements advenus dans cinq principaux types d'occupation du sol (prairie, milieu humide, milieu arbustif/ de début de succession, boisé, urbain) durant les années 1985-2016 n'ont pas permis de prédire de changement dans la population de grues. Les conditions de sécheresse ayant eu cours durant la saison de nidification précédente étaient négativement corrélées aux dénombrements du BBS, et les conditions de sécheresse prévalant dans l'année en cours étaient corrélées négativement avec les comptes de jeunes grues lors des relevés post-reproduction. Les taux de productivité de toutes les années, sauf les plus sèches, étaient similaires à ceux associés aux populations de grues stables ou en croissance. La poursuite du suivi est nécessaire puisque la longévité des grues adultes pourrait masquer une éventuelle baisse de population et parce qu'on en connait peu à propos des grues qui occupent les paysages périurbains, lesquels comptent maintenant pour une proportion grandissante de paysages de la Floride.

Key Words: Antigone canadensis; drought; land use change; population trends; productivity; Sandhill Crane

Address of Correspondent: W Andrew Cox, Lovett E. Williams Wildlife Research Lab, 1105 SW Williston Road, Gainesville, Florida, USA 32601, Andrew.Cox@myfwc.com 


\section{INTRODUCTION}

The Florida Sandhill Crane (Antigone canadensis pratensis; hereafter "crane") is a nonmigratory subspecies that occurs from southern Georgia through peninsular Florida to the Everglades (Stys 1997). The species uses a variety of habitats but prefers improved pastures, emergent wetlands, and pasture-wetland and pasture-forest transitions (Nesbitt and Williams 1990). U.S. Geological Survey Breeding Bird Survey (BBS)(Sauer et al. 2017) data from 92 active and retired BBS routes in Florida indicate that the state's population increased at an annual rate of $3.59 \%$ (95\% CI: 2.19-4.97) during 1966-2016 (Fig. 1), which suggests sustained growth for a relatively small population of birds (40006000 individuals) (Gerber et al. 2014) that has been state-listed as threatened since 1973 (FWC 2013).

Fig. 1. Temporal trend in Florida Sandhill Crane abundance in Florida, 1966-2015. Data are from the North American Breeding Bird Survey (Sauer et al. 2017), which produces an abundance index rather than actual densities to track population trends. Dashed lines indicate $95 \%$ credible intervals.

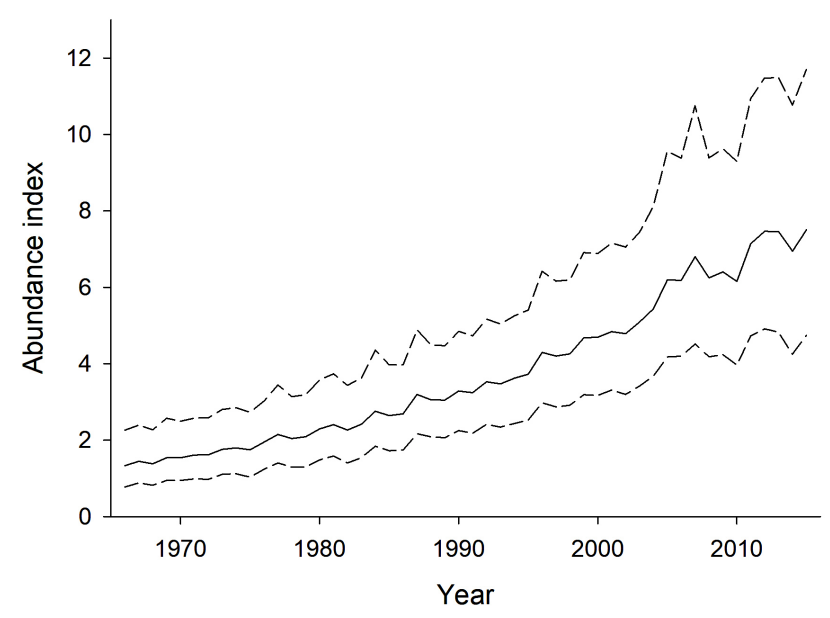

These positive population trends are somewhat surprising, given the severity of habitat loss in Florida in recent decades. During 1974-2003, > 40\% of habitat preferred by cranes was lost to development and other changes in land use, which models suggested would substantially reduce the size of Florida's crane population (Nesbitt and Hatchitt 2008). Furthermore, drought in most years between 1999 and 2014 might have been expected to reduce productivity because adequate water levels in marshes used for nesting have been positively associated with crane nest success (e.g., Littlefield 1995a), renesting rates (Bennett and Bennett 1990), juvenile survival (Nesbitt 1992), and overall recruitment (Gerber et al. 2015). In addition, many cranes now occupy suburban or urban landscapes (FWC 2013), where they can experience substantially lower nest success than in natural habitats (Toland 1999).

The incongruity between predicted population declines and the observed increase in the statewide population suggests that much remains unknown about how cranes are responding to a changing landscape and climate. To address that gap, we used BBS data from 1966 through 2016 to identify areas of Florida in which crane populations have been growing or declining. We then used a land use change data set for BBS routes in Florida (Delany et al. 2014) to correlate land use change with BBS route-specific population trends of cranes. We predicted that regions with stable or increasing crane populations would have maintained or increased wetlands and grasslands, which cranes rely on for reproduction and foraging. Finally, we explored how within-year and prior-year drought conditions affected the number of cranes detected during the BBS as well as the number of young cranes detected during a fall post-reproductive survey we conducted.

\section{METHODS}

\section{Data collection}

Florida is approximately $170,000 \mathrm{~km}^{2}$ and has a generally subtropical climate that includes a pronounced wet season during late spring through early fall. Most of Florida's primary upland terrestrial habitats were historically fire-maintained, and include scrub, pine savanna, sandhills, and hammocks. Native and nonnative (i.e., improved pasture) grasslands that Sandhill Cranes rely upon comprise $12,000 \mathrm{~km}^{2}$ of the state (FWC 2012). Florida is also characterized by its substantial wetlands, including springs, lakes, rivers, swamps, and marshes. Many wetlands are ephemeral on an annual basis, while others dry down only during prolonged droughts. Approximately $17,000 \mathrm{~km}^{2}$ of Florida are developed to some extent (FWC 2012).

We downloaded BBS data for Florida routes from 1966 to 2016 (Pardiek et al. 2017). Most BBS routes were placed randomly throughout Florida, but we also used data from nonrandomly placed BBS routes (referred to as 900-series routes) to ensure coverage of specific habitat types. The BBS is not without its potential shortcomings (reviewed by Faaborg 2002), and factors such as long-term changes in visibility or noise along roads may confound long-term trends derived from BBS data. Nevertheless, cranes are large and conspicuous, and bias related to observer effects on BBS routes was not reported for Sandhill Cranes in a study of 369 species (Sauer et al. 1994). In addition, although habitat along roadsides may not always represent the habitat in the larger landscape (Bart et al. 1995), most routes do (Veech et al. 2017), and Delany et al. (2014) demonstrated that routes in Florida were unbiased in this respect. The BBS substantially expanded the number of routes in 1987, so we performed preliminary ordinary least squares regressions for the time period prior to (1966-1986) and following (1987-2016) expansion to explore whether the increase in cranes was in part a function of expanded effort. The proportion of BBS routes with cranes increased at a similar rate during 1966-1986 (slope $=0.005$ $\pm 0.001 ; P<0.01$ ) and during 1987-2016 (slope $=0.004 \pm 0.001$; $P<0.01$ ), which suggests that the area of occupancy for cranes was increasing independent of the addition of new routes in 1987.

We collected productivity data from two non-BBS survey routes in Osceola County that totaled $126.2 \mathrm{~km}$. Routes were surveyed by a single observer once annually, in late September or early October, from 1991 to 2016, except 2012. We began surveys $1 \mathrm{hr}$ after sunrise to allow cranes time to leave their roosts and move into upland habitats, where they would be more easily seen. We drove $24-72 \mathrm{~km} / \mathrm{hr}$, counting all adult and young-of-year cranes observed within $500 \mathrm{~m}$ on either side of the road. 
We used the Palmer drought severity index (PDSI) as a proxy for the presence of drought conditions because water level data across survey routes and years were not available (data available at https://www7.ncdc.noaa.gov/CDO/CDODivisionalSelect.jsp, accessed 1 August 2017). The PDSI is a unitless, zero-centered, index of drought conditions that is calculated monthly, has been frequently used in this way in similar studies (e.g., Gerber et al. 2015), and is available for each of the seven climatic divisions in Florida. PDSI values greater than zero indicate wetter conditions, and values less than zero indicate drier conditions. We averaged monthly PDSI values from November to May to represent a breeding season drought index for each year for each climatic division in the state.

We used the most recent version of the Cooperative Land Cover data set (CLC version 3.2.5, Florida Fish and Wildlife Conservation Commission and Florida Natural Areas Inventory 2016) to assess land use change during 1985-2016, the years in which land cover data for Florida were available. We first resampled the 2016 CLC using the nearest-neighbor method to match the 30-m cell resolution of the 1985 land cover data set. Following the methodology outlined in Delany et al. (2014), we then reclassified each of the 234 land cover classifications in the CLC to six general habitat types (grassland, water/wetland, scrub/ successional, woodland, urban, and other) (Appendix 1). We applied a majority filter that gave each $30-\mathrm{m} \times 30-\mathrm{m}$ cell the most common value of its eight neighboring cells. To allow comparison of changes in land cover between the 1985 data set (which was reclassified to match the 2003 land cover data set in Delany et al. 2014) and the 2016 data set, we performed a crosswalk to match the 1985 habitat classes to the 2016 habitat classes (Appendix 1). Similar to Delany et al. (2014), we assumed that 2016 habitats were also present in 1985, and assigned the detailed 2016 habitat classes to the general classes of the 1985 data. This approach probably resulted in some level of error at the scale of the original habitat classes, but it is likely that any misclassification involved habitat classes that eventually fell within the same general habitat type. For example, some proportion of the habitat classified as rural open in 2016 might have been classified as either grassland or improved pasture in 1985, but either was treated as grassland in our analysis. We then calculated the percent change between 1985 and 2016 for each category within a 400-m buffer surrounding each BBS route and used a nonparametric sign median test to determine whether the mean value for all routes differed from zero.

\section{Analyses}

Broadly, our analysis included three distinct steps. First, we produced route-specific trend estimates from 1966 to 2016 to identify locations in Florida with growing or declining crane populations. The model included potential effects of drought because both BBS counts and PDSI data were available on an annual basis. Second, we produced route-specific trend estimates using the same model structure for 1985-2016 but with the addition of variables that described land cover changes over the same period. Third, we used the data from the non-BBS fall reproductive surveys to correlate drought with crane productivity.

We used Program R (R Development Core Team 2019), JAGS 4.3.0 (Plummer 2003), and the jagsUI package (Kellner 2019) to fit a per-route trend regression model within a Bayesian framework (Link and Sauer 2002, Sauer and Link 2011) (Appendix 2). We modeled counts (indexed by $i$ for route and $t$ for year) as independent Poisson random variables with means described by the following log-linear function (Eq. 1):

$$
\begin{aligned}
\log \left(\lambda_{i, t}\right)= & S_{i}+\beta_{i}\left(t-t^{*}\right)+\gamma_{0}\left(P D S I_{t, d(i)}\right)+ \\
& \gamma_{1}\left(P D S I_{t-1, d(i)}\right)+\varepsilon_{i, t}
\end{aligned}
$$

The predictors are route-specific intercepts $\left(S_{i}\right)$, slopes $\left(\beta_{i}\right)$ as a function of year $t$ expressed as the difference from the median year $t^{*}$, an effect $\gamma_{0}$ of winter PDSI (available for seven divisions $d$ in Florida, in one of which each route was located) in the year of the survey and an effect $\gamma_{1}$ of winter PDSI in the year preceding the survey. We included the two PDSI predictors under the assumption that nonzero current-year parameter estimates might reflect drought effects on crane observability, whereas nonzero prior-year parameter estimates might reflect drought effects on crane reproduction. Serial correlations of PDSI values were low: for the seven Florida PDSI divisions, first-order rho values from the rank von Newmann ratio test (by the serialCorrelationTest function of the EnvStats Package) (Millar 2013) were 0.24, 0.29, $0.16,0.11,0.23,0.30$, and 0.27 , with $P(\mathrm{rho}=0)=0.20,0.08,0.24$, $0.21,0.03,0.06$, and 0.15 , respectively. Furthermore, year and PDSI were not correlated (Spearman $\rho=-0.23, P=0.10)$. We estimated overdispersion effects for each route in each year. We did not include a parameter for observer effects because it does not appear to be necessary for Sandhill Cranes (Sauer et al. 1994).

We used the $\beta_{i}$ slopes as the trend estimates. We assessed a submodel for predictors on the slopes that included random effects $b_{i}$ based on the mean slope across routes and, for 19852016 models, an effect of percent change in one landcover category (Eq. 2):

$$
\beta_{i}=\varphi(\Delta 1 \text { and })+b_{i}
$$

Because percent land cover change variables were constrained to sum to 0 , and therefore necessarily at least somewhat correlated, we evaluated multiple versions of the Bayes model with one land cover change predictor at a time in the $\beta_{i}$ submodel.

We drew priors for $S_{i}$ from uniform distributions -4 to 4 . Priors for $\gamma_{0}, \gamma_{1} \varphi$, and the statewide average trend were from a normal distribution with mean 0 and precision $(1 /$ variance $)=0.001$. We drew priors for $\varepsilon_{i, t}$ from mean-zero normal distributions with variances drawn from inverse gamma distributions whose scale and shape parameters were 0.001 . We drew those for $b_{i}$ from normal distributions with the statewide average as means and variances from inverse gamma prior distributions whose scale and shape parameters were 0.001 .

We performed 100,000 iterations of the model with a burn-in period of 60,000 with three chains and a thinning rate of 5 . We assessed goodness of fit with a posterior predictive check based on Chi-square discrepancies of the actual and fitted data (e.g., Kéry and Royle 2016). The posterior predictive check indicated acceptable fits for the 1966-2016 model (Bayesian $P=0.43$ ) and for the 1985-2016 model (Bayesian $P=0.39$ ) before adding any land cover change. We considered a Bayesian parameter estimate to be significant if its $95 \%$ credible interval (CI) excluded 0 . 
Preliminary analyses indicated that some route-level trends were poorly estimated because of extremely small sample sizes, so we included only routes for which cranes were reported in $\geq 4$ years ( $n=46$ routes). Two of the remaining routes ( 25170 and 25172$)$ that were nearly identical to older routes (25070 and 25072) were merged with the older routes, and two older routes (25013 and 25016) were discarded because we felt they were too dissimilar from the routes that replaced them (25113 and 25116) to be merged. Our final sample size was 42 routes, 11 of which ran from 1966 to 2016 and 31 of which ran from 1987 to 2016.

We used the Getis-Ord Gi* statistic (Getis and Ord 1992) using the Optimized Hot Spot Analysis tool in ArcGIS (version 10.3.1; Esri, Redlands, California, USA) to identify areas for which population increases or decreases clustered spatially. We first created "route neighborhood" polygons using Euclidean allocation (Delany et al. 2014). We then used the Optimized Hot Spot Analysis tool to assess each route neighborhood polygon's population trend in the context of nearby polygons. To be a statistically significant hot spot, a feature must have a high value and be surrounded by other polygons with a high value.

We calculated productivity by dividing the total number of youngof-the-year by the total number of cranes for which we could determine age (adults and young-of-the-year). We then used ordinary linear regression to relate productivity and the November-May average PDSI values (from Climatic Division 4, in which the routes were located) for each breeding season.

\section{RESULTS}

Crane populations increased on 17 routes, with annual growth rates between $4 \%$ and $12 \%$ (route-specific raw counts and trend lines are presented in Appendix 3). Populations decreased on one route, and there was no evidence of significant population growth or decline on 24 routes. Routes where crane populations increased occurred throughout the breeding range, but the Getis-Ord Gi* analysis suggested that there was a spatial cluster of three routes ( $z$ scores $=2.7,2.3$, and $2.1 ; P=<0.01,0.02$, and 0.03 , respectively) with positive population growth in the northwestern part of the breeding range (Fig. 2).

During 1966-2016, counts in a given year were negatively correlated with increased drought (i.e., a negative PDSI value) in the prior year $\left(\gamma_{1}=0.037,95 \%\right.$ CI: $\left.0.005-0.070\right)$. During $1985-$ 2016, counts were positively correlated with increased drought within the current year $\left(\gamma_{0}=-0.049,95 \% \mathrm{CI}:-0.081--0.016\right)$ and negatively associated with increased drought in the previous year $\left(\gamma_{1}=0.038,95 \%\right.$ CI: $\left.0.005-0.070\right)$. Values presented are from the log linear with urban land cover change, but results were consistent across land cover models. The magnitude of the effect of PDSI covariates was small, however, and route-specific population trends were similar whether the PDSI parameters were included or excluded from the model.

Grassland and scrub/successional land covers declined significantly in the BBS route buffers, while the urban land cover increased considerably (Table 1). However, we detected no effect of landcover change on Sandhill Crane populations despite the significant landcover changes observed along BBS routes. Specifically, we found no evidence of an effect of change in wetland $(\varphi$ wetland $=0.0,95 \%$ CI: $-0.004-0.004)$, woodland, $\left(\varphi_{\text {woodland }}=-0.001,95 \% \mathrm{CI}:-0.0 .003-0.001\right)$, grassland $\left(\varphi_{\text {grassland }}\right.$
$=-0.001,95 \% \mathrm{CI}:-0.003-0.001), \operatorname{scrub}\left(\varphi_{\mathrm{scrub}}=0.0,95 \% \mathrm{CI}:\right.$ $-0.004-0.004)$, or urban $(\varphi$ urban $=0.001,95 \%$ CI: $0.0-0.003)$ landcover on Sandhill Crane population trends.

Fig. 2. Breeding Bird Survey route-specific population trends of Florida cranes, 1966-2016. Each polygon represents the neighborhood of each route, with polygon borders defined by the proximity to neighboring routes. Blue circles represent the estimated number of birds for each route from 2016 as derived from its population trend. The orange ellipse indicates the cluster of routes that is a significant hot spot of population growth.

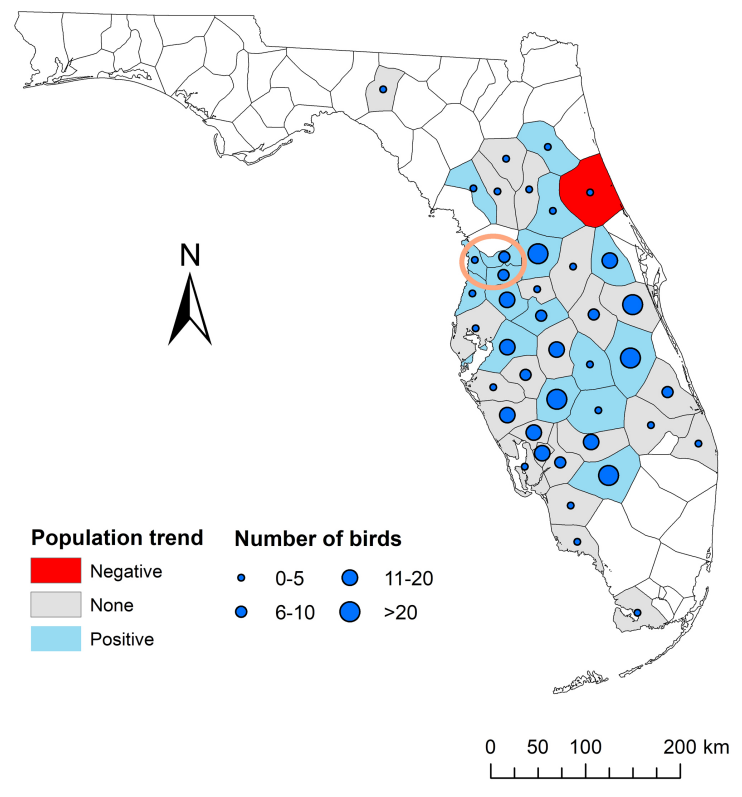

Average annual productivity from the fall post-reproductive survey was $11.8 \% \pm 1.0 \mathrm{SE}$ (min: $4.0 \%$, max: $19.9 \%$ ). Drought during the breeding season was negatively correlated with productivity, with fewer juvenile cranes counted in the falls following drier breeding season conditions $(P<0.01)$ (Fig. 3).

Fig. 3. Fall recruitment of Florida Sandhill Cranes on two roadside surveys as a function of the Palmer drought severity index (PDSI). PSDI values less than zero indicate drier than normal conditions.

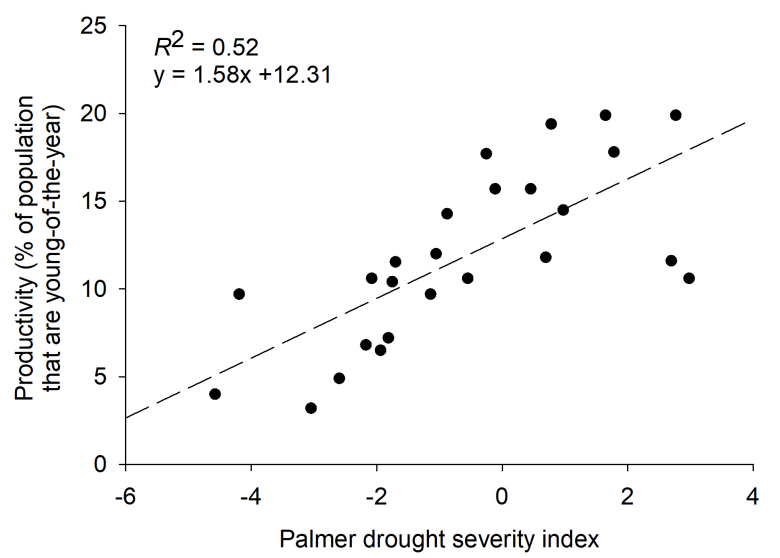


Table 1. Summary statistics for differences in percentage land cover categories for 42 BBS route buffer areas in Florida, 1985-2016

\begin{tabular}{|c|c|c|c|c|c|c|c|c|c|}
\hline \multirow[b]{2}{*}{ Route buffer land cover ${ }^{\dagger}$} & \multirow[b]{2}{*}{ Min } & \multirow[b]{2}{*}{$\begin{array}{c}\text { Lower } \\
\text { quartile }\end{array}$} & \multirow[b]{2}{*}{ Median } & \multirow[b]{2}{*}{ Upper quartile } & \multirow[b]{2}{*}{$\operatorname{Max}$} & \multicolumn{4}{|c|}{ Mean } \\
\hline & & & & & & Mean & S.D. & $\mathrm{LCL}$ & $\mathrm{UCL}$ \\
\hline Grassland & -38.81 & -11.81 & $-3.42 *$ & 0.45 & 12.44 & -5.21 & 1.43 & -8.10 & -2.32 \\
\hline Wetland/open water & -32.70 & -2.76 & 0.20 & 2.77 & 15.53 & -0.24 & 1.10 & -2.46 & 1.98 \\
\hline Scrub/successional & -38.57 & -13.53 & $-6.83^{*}$ & -1.98 & 2.09 & -8.83 & 1.45 & -11.75 & -5.90 \\
\hline Woodland & -23.38 & -2.37 & 2.69 & 5.25 & 52.48 & 2.43 & 1.95 & -1.51 & 6.38 \\
\hline Urban & -16.39 & 4.35 & $13.17^{*}$ & 24.38 & 51.49 & 16.59 & 2.29 & 11.96 & 21.21 \\
\hline Other & -21.37 & -9.97 & $-4.96^{*}$ & -1.48 & 26.70 & -4.74 & 1.38 & -7.53 & -1.96 \\
\hline
\end{tabular}

${ }^{\dagger}$ Confidence intervals are approximate rather than exact for all land cover types except urban because the variables were not normally distributed.

*Median value differed significantly from zero.

\section{DISCUSSION}

Local Florida Sandhill Crane populations appear to be stable or growing in Florida despite the loss of $>40 \%$ of the subspecies' preferred habitat during 1974-2003 (Nesbitt and Hatchitt 2008). The routes with positive population trends were located throughout the breeding range in Florida, and the single route with a negative trend was located on the periphery of the species' range, indicating that to date there is no hot spot of regional decline in Florida.

The model that used all data available from 1966 to 2016 estimated 17 positive route-specific population trends and included a significant positive PDSI $_{t-1}$ parameter, which suggests that crane populations increased despite the negative effect of drought conditions in the year prior to a survey. These results mirror those from the productivity surveys which clearly demonstrated the negative relationship between drought conditions and productivity, which declines during drought years because of reduced nesting rates (Thompson 1970), nesting success (Littlefield 1995a), renesting rates (Bennett and Bennett 1990), and juvenile survival (Nesbitt 1992). As such, it is intuitive that fewer young produced during a drought year would result in a reduced number of birds counted during a BBS survey in the subsequent year.

Results from the same model that incorporated land cover change data but was limited to 1985-2016 also included a significant negative PSDI ${ }_{t}$ parameter, which indicates that at least in a subset of our data, breeding season counts of cranes were greater when within-season drought conditions were worse. We did not anticipate this relationship and interpret it with caution because it was not supported in the entire data set. However, it could occur because of the tendency of cranes to abandon nests, make fewer renesting attempts, or forgo nesting in dry years (Thompson 1970; T. Dellinger, unpublished data). Fewer nesting cranes would result in more cranes foraging in pastures and fields where they are less concealed than when incubating eggs in marshes that are often characterized by dense emergent vegetation.

The substantial drought conditions that frequently occurred in the most recent years of the survey coupled with the possibility of within-year drought inflating counts might suggest that some of the positive population growth documented by BBS data may have been biased high by crane behavior during dry years. Longterm changes in roadside mowing and tree trimming could also affect our results, as more regular mowing in recent years could increase the amount of pasture that was open to observation and thus increase raw counts. However, based on our experience in the field, these issues account for at most a small fraction of the overall positive population trends the BBS has documented in Florida.

It is somewhat surprising that populations continued to grow during 1999-2014 because of the frequency of dry years during that period and the pronounced effect of drought on reproduction. But Sandhill Cranes are long-lived (Gerber et al. 2015), and recruitment rates can be relatively low and still support a stable or growing population. Drewien (1973) associated a 13\% juvenile/adult ratio with a growing Sandhill Crane population in Idaho, and slightly lower recruitment rates (8-10\% in Littlefield and Ryder [1968]; 8.3\% for the Rocky Mountain population in Kruse et al. [2014]) have been associated with stable populations elsewhere (but see Arnold et al. 2016, who suggest that a 15\% recruitment rate is necessary for a stable population on the basis of juvenile and adult survivorship). Our data indicate that recruitment was $>10 \%$ in all but the driest years, and in many years it was substantially greater (Fig. 3). With respect to adult survival, we are not aware of data that demonstrate the effects of drought on the survivorship of adult Sandhill Cranes, but adult survival of the Whooping Crane (Grus americana) was the least variable demographic parameter across 36 years (Wilson et al. 2016). Cranes may be able to survive well in all but the most severe drought conditions, in part by reducing or eliminating breeding efforts.

We predicted that crane populations would increase in areas of the state that maintained or increased grassland acreage during 1985-2016. Our results did not support our predictions and instead suggested that land cover change was not associated with crane population trends. The BBS route paths that we used in our analyses are not regularly updated by BBS staff (D. Ziolkowski, personal communication), so it is probable that many of the point counts that comprised each route survey did not occur along the exact path we used to derive our land cover change data. The disconnect between the true location of some counts and the land cover change data we used may in part explain why no land cover predictors explained crane population trends. However, we would also suggest that formulating predictions of population trends based on land cover change is not always straightforward and may be ineffective when the land cover types that are lost are similar to other habitat types. For cranes, suburban areas in Florida often offer short grasses and wetlands that may 
approximate natural habitat and thus mitigate the negative effects of the loss of natural areas.

We also did not find support for our prediction that population trends would be positively correlated with changes in wetland cover. However, the shallow, often ephemeral wetlands that cranes use for nesting are one of many types of wetlands found in Florida, and the lack of a significant result may be a consequence of our combining all wetland types into one habitat class. We chose this approach to stay consistent with Delany et al. (2014) and because we felt it would be resistant to large-scale classification errors, but such error might have added noise to the data and reduced our ability to detect the effect of wetland loss or gain on population trends.

Our results derived from BBS data suggest that crane populations are stable or growing across much of the subspecies' core breeding range in Florida. These data are concordant with those from the fall reproductive surveys, which indicate that populations in central Florida reproduce at rates sufficient to maintain or increase local populations in all but the driest years. The Sandhill Crane appears to be a resilient species, capable of adapting to new landscapes as long as its fundamental nesting and foraging requirements are met. Nevertheless, land cover change is expected to continue, as Florida's population is projected to increase by 3.6-9.2 million people between 2013 and 2040 (Smith and Rayer 2014 ), and $88 \%$ of the crane's historically preferred habitat within its present range is privately owned and thus unprotected from development (Nesbitt and Hatchitt 2008). As such, continued monitoring of Florida Sandhill Crane productivity is warranted because cranes' longevity can mask an impending population decline (Littlefield 1995b). More work is also required to understand survivorship, productivity, and habitat use in suburban and residential landscapes that continue to expand in Florida, and upon which the continued persistence of Florida's resident Sandhill Crane population may depend.

Responses to this article can be read online at: http://www.ace-eco.org/issues/responses.php/1519

\section{Acknowledgments:}

Funding for this study was provided by the State of Florida's Nongame Trust Fund. We thank S. Baynes, R. Butryn, M. Folk, J. Redner, and M. Watford. K. Miller, E. Ragheb, and three anonymous reviewers offered feedback that greatly improved this manuscript. All applicable ethical guidelines for the use of birds in research were followed, including those presented in the Ornithological Council's Guidelines to the Use of Wild Birds in Research.

\section{LITERATURE CITED}

Arnold, T. W., C. N. De Sobrino, and H. M. Specht. 2016. Annual survival rates of migratory shore and upland game birds. Wildlife Society Bulletin 40:470-476. https://doi.org/10.1002/wsb.669

Bart, J., M. Hofschen, and B. G. Peterjohn. 1995. Reliability of the Breeding Bird Survey: effects of restricting surveys to roads. Auk 112:758-761.
Bennett, A. J., and L. A. Bennett. 1990. Productivity of Florida Sandhill Cranes in the Okeefenokee Swamp, Georgia. Journal of Field Ornithology 61:224-231.

Delany, M. F., R. A. Kiltie, and R. S. Butryn. 2014. Land cover along Breeding Bird Survey routes in Florida. Florida Field Naturalist 42:15-28.

Drewien, R. C. 1973. Ecology of Rocky Mountain Greater Sandhill Cranes. Dissertation. University of Idaho, Moscow, Idaho, USA.

Faaborg, J. 2002. Saving migrant birds. University of Texas Press, Austin, Texas, USA.

Florida Fish and Wildlife Conservation Commission (FWC). 2012. Florida's Wildlife Legacy Initiative: Florida's State Wildlife Action Plan. Tallahassee, Florida, USA.

Florida Fish and Wildlife Conservation Commission (FWC). 2013. A species action plan for the Florida Sandhill Crane. Tallahassee, Florida, USA.

Gerber, B. D., J. F. Dwyer, S. A. Nesbitt, R. C. Drewien, C. D. Littlefield, T. C. Tacha, and P. A. Vohs. 2014. Sandhill Crane (Antigone canadensis). In P. G. Rodewald, editor. The birds of North America. Cornell Lab of Ornithology, Ithaca, New York, USA. [online] URL: https://doi.org/10.2173/bna.31

Gerber, B. D., W. L. Kendall, M. B. Hooten, J. A. Dubovsky, and R. C. Drewien. 2015. Optimal population prediction of Sandhill Crane recruitment based on climate-mediated habitat limitations. Journal of Animal Ecology 84:1299-1310. https://doi. org/10.1111/1365-2656.12370

Getis, A., and J. K. Ord. 1992. The analysis of spatial association by use of distance statistics. Geographical Analysis 24:189-206. https://doi.org/10.1111/j.1538-4632.1992.tb00261.x

Kellner, K. 2019. jagsUI: a wrapper around 'rjags' to streamline 'JAGS' analyses. R package version 1.5.1. [online] URL: https:// CRAN.R-project.org/package=jagsUI

Kéry, M., and J. A. Royle. 2016. Applied hierarchical modeling in ecology: analysis of distribution, abundance and species richness in $R$ and BUGS: Volume 1: prelude and static models. Academic Press, London, UK.

Kruse, K. L., J. A. Dubovsky, and T. R. Cooper. 2014. Status and harvests of Sandhill Cranes: mid-continent, Rocky Mountain, lower Colorado River Valley, and eastern populations. Administrative Report, U.S. Fish and Wildlife Service, Lakewood, Colorado, USA.

Link, W. A., and J. R. Sauer. 2002. A hierarchical analysis of population change with application to Cerulean Warblers. Ecology 83:2832-2840. https://doi.org/10.1890/0012-9658(2002) 083[2832:AHAOPC]2.0.CO;2

Littlefield, C. D. 1995a. Greater Sandhill Crane nesting and production in northeastern California, 1988. Western Birds 26:34-38.

Littlefield, C. D. 1995b. Demographics of a declining flock of Greater Sandhill Cranes in Oregon. Wilson Bulletin 107:667-674.

Littlefield, C. D., and R. A. Ryder. 1968. Breeding biology of the Greater Sandhill Crane on Malheur National Wildlife Refuge, 
Oregon. Transactions of the North American Wildlife and Natural Resources Conference 33:444-454.

Millar, S. P. 2013. EnvStats, an R Package for environmental statistics. Springer, New York.

Nesbitt, S. A. 1992. First reproductive success and individual productivity in Sandhill Cranes. Journal of Wildlife Management 56:573-577. https://doi.org/10.2307/3808874

Nesbitt, S. A., and J. L. Hatchitt. 2008. Trends in habitat and population of Florida Sandhill Cranes. Proceedings of the North American Crane Workshop 10:40-42.

Nesbitt, S. A., and K. S. Williams. 1990. Home range and habitat use of Florida Sandhill Cranes. Journal of Wildlife Management 54:92-96. https://doi.org/10.2307/3808907

Pardieck, K. L., D. J. Ziolkowski, Jr., M. Lutmerding, K. Campbell, and M.-A.R. Hudson. 2017. North American Breeding Bird Survey dataset 1966-2016, version 2016.0. U.S. Geological Survey, Patuxent Wildlife Research Center, Laurel, Maryland, USA. [online] URL: www.pwrc.usgs.gov/BBS/RawData/

Plummer, M. 2003. JAGS: a program for analysis of Bayesian graphical models using Gibbs sampling. In K. Homik, F. Leisch, and A. Zeileis, editors. Proceedings of the 3rd International Workshop on Distributed Statistical Computing (DSC 2003). Vienna University, Vienna, Austria.

R Development Core Team. 2019. R: a language and environment for statistical computing. R Foundation for Statistical Computing, Vienna, Austria. [online] URL https://www.R-project.org/

Sauer, J. R., and W. A. Link. 2011. Analysis of the North American Breeding Bird Survey using hierarchical models. Auk 128:87-98. https://doi.org/10.1525/auk.2010.09220

Sauer, J. R., D. K., Niven, J. E Hines, D. J. Ziolkowski, Jr., K. L. Pardieck, J. E. Fallon, and W. A. Link. 2017. The North American Breeding Bird Survey, results and analysis 1966-2015. Version 2.07.2017. U.S. Geological Survey, Patuxent Wildlife Research Center, Laurel, Maryland, USA. [online] URL: https://www.mbrpwrc.usgs.gov/bbs/

Sauer, J. R., B. G. Peterjohn, and W. A. Link. 1994. Observer differences in the North American Breeding Bird Survey. Auk 111:50-62. https://doi.org/10.2307/4088504

Smith, S. K., and S. Rayer. 2014. Projections of Florida population by county, 2015-2040, with estimates for 2013. Bureau of Economic and Business Research, Florida Population Studies, Volume 47.

Stys, B. 1997. Ecology of the Florida Sandhill Crane. Nongame Wildlife Program Technical Report No. 15. Office of Environmental Services, Florida Game and Fresh Water Fish Commission, Tallahassee, Florida, USA.
Thompson, R. L. 1970. Florida Sandhill Crane nesting on the Loxahatchee National Wildlife Refuge. Auk 87:492-502. https:// doi.org/10.2307/4083792

Toland, B. 1999. Nesting success and productivity of Florida Sandhill Cranes on natural and developed sites in southeast Florida. Florida Field Naturalist 27:10-13.

Veech, J. A., K. L. Pardieck, and D. J. Ziolkowski, Jr. 2017. How well do route survey areas represent landscapes at larger spatial extents? An analysis of land cover composition along Breeding Bird Survey routes. Condor 119:607-615. https://doi.org/10.1650/ CONDOR-17-15.1

Wilson, S., K. C. Gil-Weir, R. G. Clark, G. J. Robertson, and M. T. Bidwell. 2016. Integrated population modeling to assess demographic variation and contributions to population growth for endangered Whooping Cranes. Biological Conservation 197:1-7. https://doi.org/10.1016/j.biocon.2016.02.022
Editor-in-Chief: Keith A.Hobson Subject Editor: Steven L.Van Wilgenburg

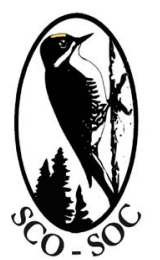

Sponsored by the Society of Canadian Ornithologists and Birds Canada

Parrainée par la Société des ornithologistes du Canada et Oiseaux Canada

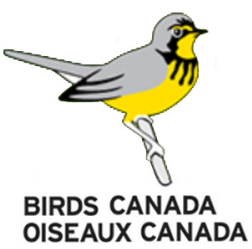


Appendix 1. Crosswalk Between 1985 (As Modified in Delany 2014) And 2016 Land Cover Data Sets.

\begin{tabular}{|c|c|c|}
\hline Land cover category & Land cover class in 1985 and 2003 & Land cover class 2016 \\
\hline \multirow{10}{*}{ Grassland } & Dry Prairie & Dry Prairie \\
\hline & \multirow{6}{*}{ Grasslands } & Mowed Grass \\
\hline & & Rural Open \\
\hline & & Reclaimed Lands \\
\hline & & Palmetto Prairie \\
\hline & & Cropland/Pasture \\
\hline & & Other Open Lands - Rural \\
\hline & Improved Pasture & Improved Pasture \\
\hline & \multirow{2}{*}{ Unimproved Pasture } & Oak - Cabbage Palm Forests \\
\hline & & Unimproved/Woodland Pasture \\
\hline \multirow{13}{*}{ Scrub/successional } & \multirow{6}{*}{ Coastal Strand } & Coastal Uplands \\
\hline & & Beach Dune \\
\hline & & Coastal Berm \\
\hline & & Coastal Grassland \\
\hline & & Coastal Strand \\
\hline & & Shell Mound \\
\hline & Sand Pine Scrub & Sand Pine Scrub \\
\hline & \multirow{2}{*}{ Shrub and Brushland } & Shrub and Brushland \\
\hline & & Other Shrubs and Brush \\
\hline & \multirow{4}{*}{ Xeric Oak Scrub } & Scrub \\
\hline & & Oak Scrub \\
\hline & & Rosemary Scrub \\
\hline & & Coastal Scrub \\
\hline \multirow{21}{*}{ Urban } & \multirow{9}{*}{ High Impact Urban } & High Intensity Urban \\
\hline & & Transportation \\
\hline & & Roads \\
\hline & & Rails \\
\hline & & Residential, Med. Density - 2-5 Dwelling Units/AC \\
\hline & & Residential, High Density > 5 Dwelling Units/AC \\
\hline & & Commercial and Services \\
\hline & & Industrial \\
\hline & & Institutional \\
\hline & \multirow{12}{*}{ Low Impact Urban } & Cultural - Terrestrial \\
\hline & & Vegetative Berm \\
\hline & & Highway Rights of Way \\
\hline & & Low Intensity Urban \\
\hline & & Rural Structures \\
\hline & & Communication \\
\hline & & Utilities \\
\hline & & Urban Open Land \\
\hline & & Residential, Low Density \\
\hline & & Grass \\
\hline & & Trees \\
\hline & & Rural Open Forested \\
\hline
\end{tabular}




\begin{tabular}{|c|c|c|}
\hline Land cover category & Land cover class in 1985 and 2003 & Land cover class 2016 \\
\hline \multirow{8}{*}{ Urban } & \multirow{8}{*}{ Low Impact Urban } & Rural Open Pine \\
\hline & & Urban Open Forested \\
\hline & & Urban Open Pine \\
\hline & & Parks and Zoos \\
\hline & & Golf courses \\
\hline & & Ballfields \\
\hline & & Cemeteries \\
\hline & & Community rec. facilities \\
\hline \multirow{42}{*}{ Wetland/open water } & \multirow{5}{*}{ Cypress Swamp } & Cypress/Tupelo(incl Cy/Tu mixed) \\
\hline & & Cypress \\
\hline & & Isolated Freshwater Swamp \\
\hline & & Strand Swamp \\
\hline & & Floodplain Swamp \\
\hline & \multirow{37}{*}{ Freshwater Marsh and Wet Prairie } & Freshwater Non-Forested Wetlands \\
\hline & & Prairies and Bogs \\
\hline & & Wet Prairie \\
\hline & & Marl Prairie \\
\hline & & Seepage Slope \\
\hline & & Marshes \\
\hline & & Isolated Freshwater Marsh \\
\hline & & Coastal Interdunal Swale \\
\hline & & Floodplain Marsh \\
\hline & & Slough Marsh \\
\hline & & Floating/Emergent Aquatic Vegetation \\
\hline & & Slough \\
\hline & & Water Lettuce \\
\hline & & Duck Weed \\
\hline & & Water Lily \\
\hline & & Submergent Aquatic Vegetation \\
\hline & & Non-vegetated Wetland \\
\hline & & Cultural - Palustrine \\
\hline & & Impounded Marsh \\
\hline & & Grazed Wetlands \\
\hline & & Clearcut Wetland \\
\hline & & Cutthroat Seep \\
\hline & & Depression Marsh \\
\hline & & Basin Marsh \\
\hline & & Freshwater Tidal Marsh \\
\hline & & Mangrove Swamp \\
\hline & & Buttonwood Forest \\
\hline & & Lacustrine \\
\hline & & Natural Lakes and Ponds \\
\hline & & Limnetic \\
\hline & & Clastic Upland Lake \\
\hline & & Coastal Dune Lake \\
\hline & & Flatwoods/Prairie/Marsh Lake \\
\hline & & River Floodplain Lake/Swamp Lake \\
\hline & & Sinkhole Lake \\
\hline & & Coastal Rockland Lake \\
\hline & & Sandhill Lake \\
\hline
\end{tabular}




\begin{tabular}{|c|c|c|}
\hline Land cover category & Land cover class in 1985 and 2003 & Land cover class 2016 \\
\hline \multirow[t]{8}{*}{ Wetland/open water } & Freshwater Marsh and Wet Prairie & $\begin{array}{l}\text { Major Springs } \\
\text { Littoral } \\
\text { Cultural - Lacustrine } \\
\text { Artificial/Farm Pond } \\
\text { Aquacultural Ponds } \\
\text { Artificial Impoundment/Reservoir } \\
\text { Quarry Pond } \\
\text { Sewage Treatment Pond } \\
\text { Stormwater Treatment Areas } \\
\text { Industrial Cooling Pond } \\
\text { Riverine } \\
\text { Natural Rivers and Streams } \\
\text { Alluvial Stream } \\
\text { Blackwater Stream } \\
\text { Spring-run Stream } \\
\text { Seepage Stream } \\
\text { Tidally-influenced Stream } \\
\text { Riverine Sandbar } \\
\text { Cultural - Riverine } \\
\text { Canal } \\
\text { Ditch/Artificial Intermittent Stream } \\
\text { Estuarine } \\
\text { Subtidal }\end{array}$ \\
\hline & Open Water & $\begin{array}{l}\text { Oyster Bar } \\
\text { Cultural - Estuarine } \\
\text { Estuarine Ditch/Channel } \\
\text { Estuarine Artificial Impoundment } \\
\text { Marine } \\
\text { Surf Zone } \\
\text { Unconsolidated Substrate }\end{array}$ \\
\hline & Salt Marsh & Salt Marsh \\
\hline & Sand/Beach & Sand Beach (Dry) \\
\hline & Sawgrass Marsh & $\begin{array}{l}\text { Glades Marsh } \\
\text { Sawgrass }\end{array}$ \\
\hline & Scrub Mangrove & $\begin{array}{l}\text { Keys Cactus Barren } \\
\text { Scrub Mangrove } \\
\text { Keys Tidal Rock Barren }\end{array}$ \\
\hline & Shrub Swamp & $\begin{array}{l}\text { Mixed Scrub-Shrub Wetland } \\
\text { Shrub Bog }\end{array}$ \\
\hline & Tidal Flat & $\begin{array}{l}\text { Intertidal } \\
\text { Exposed Limestone } \\
\text { Non-vegetated } \\
\text { Tidal Flat } \\
\text { Mud } \\
\text { Sand }\end{array}$ \\
\hline
\end{tabular}




\begin{tabular}{|c|c|c|}
\hline Land cover category & Land cover class in 1985 and 2003 & Land cover class 2016 \\
\hline \multirow{48}{*}{ Woodland } & \multirow{3}{*}{ Bay Swamp } & Baygall \\
\hline & & Bay Swamp \\
\hline & & South Florida Bayhead \\
\hline & \multirow{2}{*}{ Bottomland Hardwood Forest } & Bottomland Forest \\
\hline & & Alluvial Forest \\
\hline & \multirow{3}{*}{ Cabbage Palm-Live Oak Hammock } & Prairie Mesic Hammock \\
\hline & & Live Oak \\
\hline & & Cabbage Palm \\
\hline & \multirow{2}{*}{ Cypress } & Dome Swamp \\
\hline & & Basin Swamp \\
\hline & \multirow{4}{*}{ Cypress/Pine/Cabbage Palm } & Other Coniferous Wetlands \\
\hline & & Pond Pine \\
\hline & & Atlantic White Cedar \\
\hline & & Cypress/Pine/Cabbage Palm \\
\hline & \multirow{7}{*}{ Hardwood Hammocks and Forest } & Upland Hardwood Forest \\
\hline & & Dry Upland Hardwood Forest \\
\hline & & Mixed Hardwoods \\
\hline & & Mesic Hammock \\
\hline & & Pine - Mesic Oak \\
\hline & & Slope Forest \\
\hline & & Xeric Hammock \\
\hline & \multirow{5}{*}{ Hardwood Swamp } & Tupelo \\
\hline & & Other Hardwood Wetlands \\
\hline & & Mixed Wetland Hardwoods \\
\hline & & Titi Swamp \\
\hline & & Gum Pond \\
\hline & \multirow{4}{*}{ Hydric Hammock } & Hydric Hammock \\
\hline & & Coastal Hydric Hammock \\
\hline & & Prairie Hydric Hammock \\
\hline & & Cabbage Palm Hammock \\
\hline & \multirow{3}{*}{ Mixed Pine-Hardwood Forest } & Upland Mixed Woodland \\
\hline & & Mixed Hardwood-Coniferous \\
\hline & & Successional Hardwood Forest \\
\hline & \multirow{5}{*}{ Mixed Wetland Forest } & Freshwater Forested Wetlands \\
\hline & & Other Wetland Forested Mixed \\
\hline & & Cypress/Hardwood Swamps \\
\hline & & Impounded Swamp \\
\hline & & Freshwater Tidal Swamp \\
\hline & \multirow{10}{*}{ Pinelands } & Upland Coniferous \\
\hline & & Upland Pine \\
\hline & & Pine Flatwoods and Dry Prairie \\
\hline & & Dry Flatwoods \\
\hline & & Mesic Flatwoods \\
\hline & & Scrubby Flatwoods \\
\hline & & Pine Rockland \\
\hline & & Wet Flatwoods \\
\hline & & Wet Coniferous Plantation \\
\hline & & Tree Plantations \\
\hline
\end{tabular}




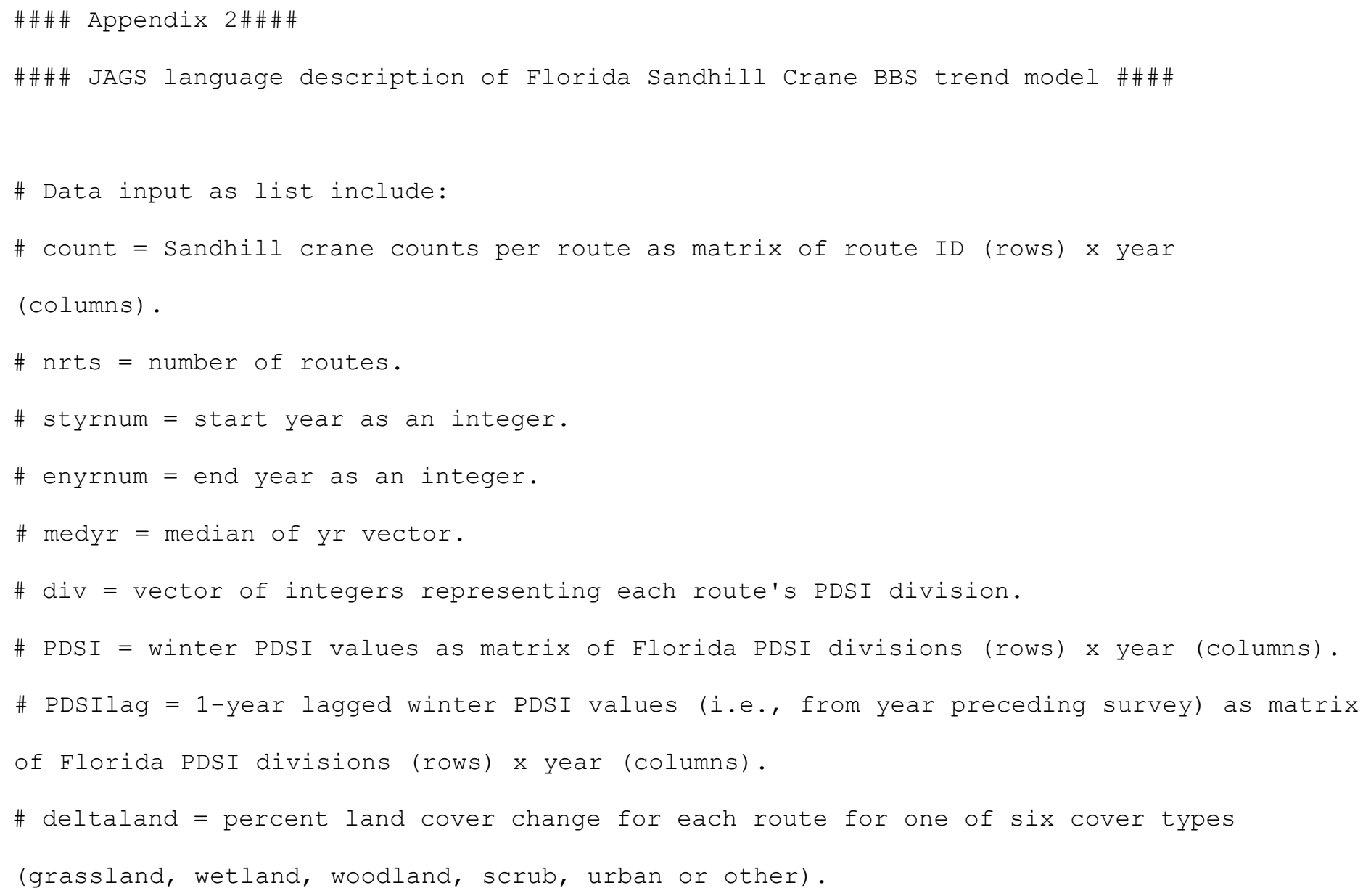


\#beta[i] <- phi*deltaland[i] + b[i] \#for 1985-2016 models with landcover change effect

$\mathrm{b}[\mathrm{i}] \sim \operatorname{dnorm}(\mathrm{B} 1, \mathrm{tau} . \mathrm{b})$

\section{\}}

\#Priors:

for (i in $1:$ nrts) \{

S [i] dunif $(-4,4)$

\}

tau.b $\sim$ dgamma $(0.001,0.001)$

phi $\operatorname{dnorm}(0,0.01)$

B1 $\sim \operatorname{dnorm}(0,0.01)$

gamma $\sim \operatorname{dnorm}(0,0.001)$

gammalag $\sim \operatorname{dnorm}(0,0.001)$

tau.epsilon dgamma $(0.001,0.001)$

\}\#end model 
Appendix 3. Breeding Bird Survey Route-Specific Trends

Fig. A3.1. Route-specific raw counts (black circles) and trend lines (blue, red, and gray lines indicate significantly positive, significantly negative, and no trends, respectively) for 42 Breeding Bird Survey routes for which data were available from 1966 through 2016. Trends are estimated from the model described in Appendix 2.
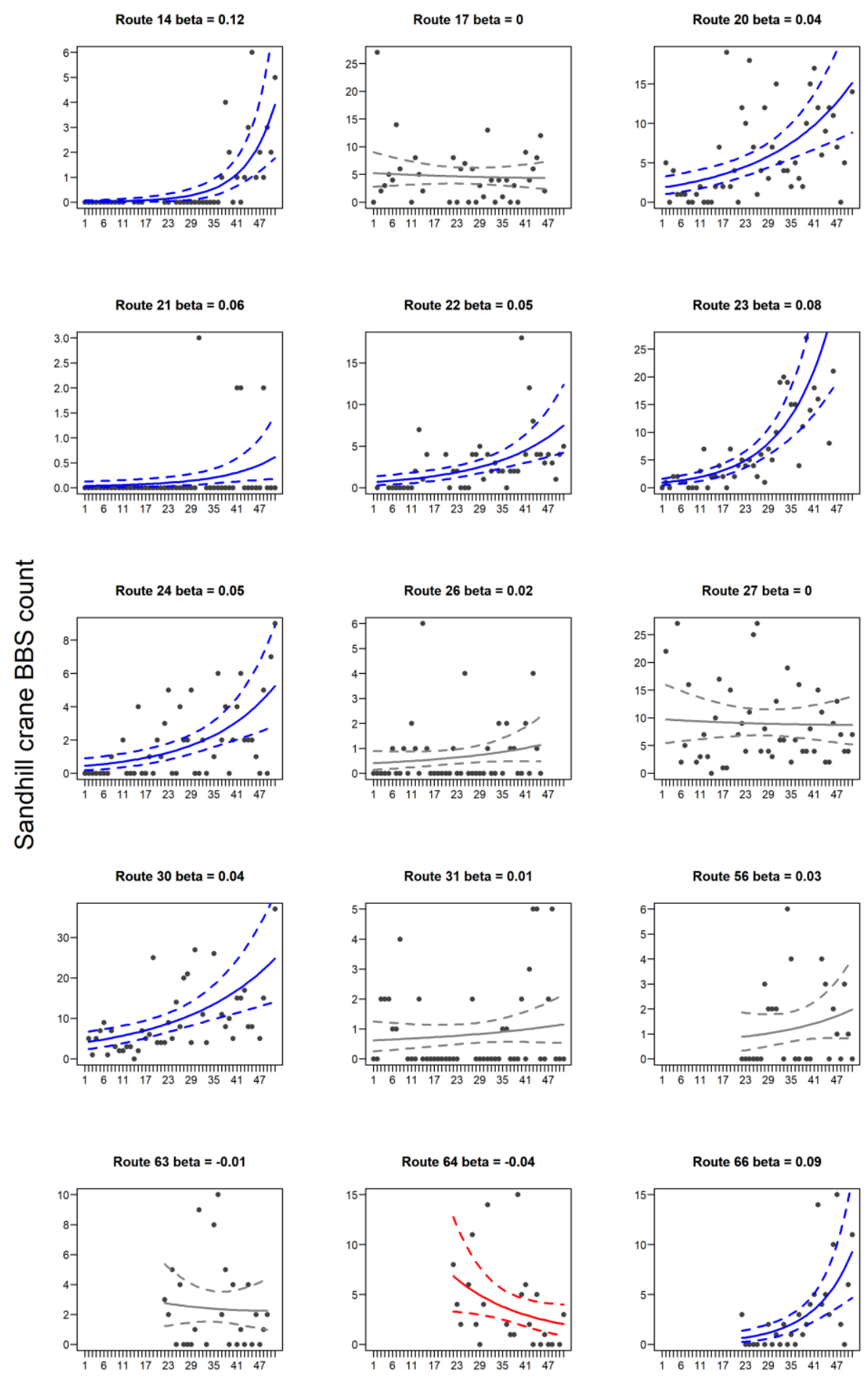

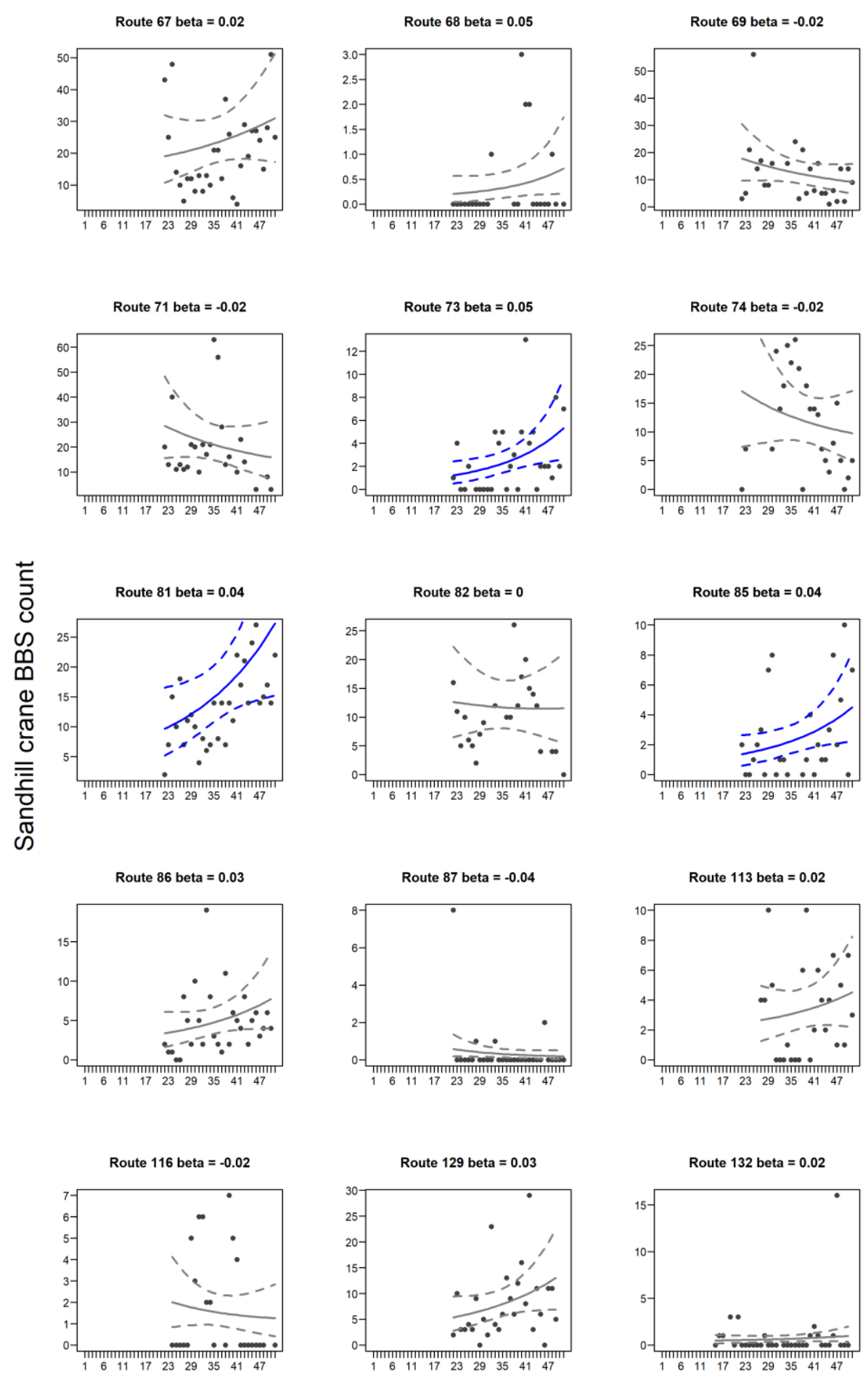

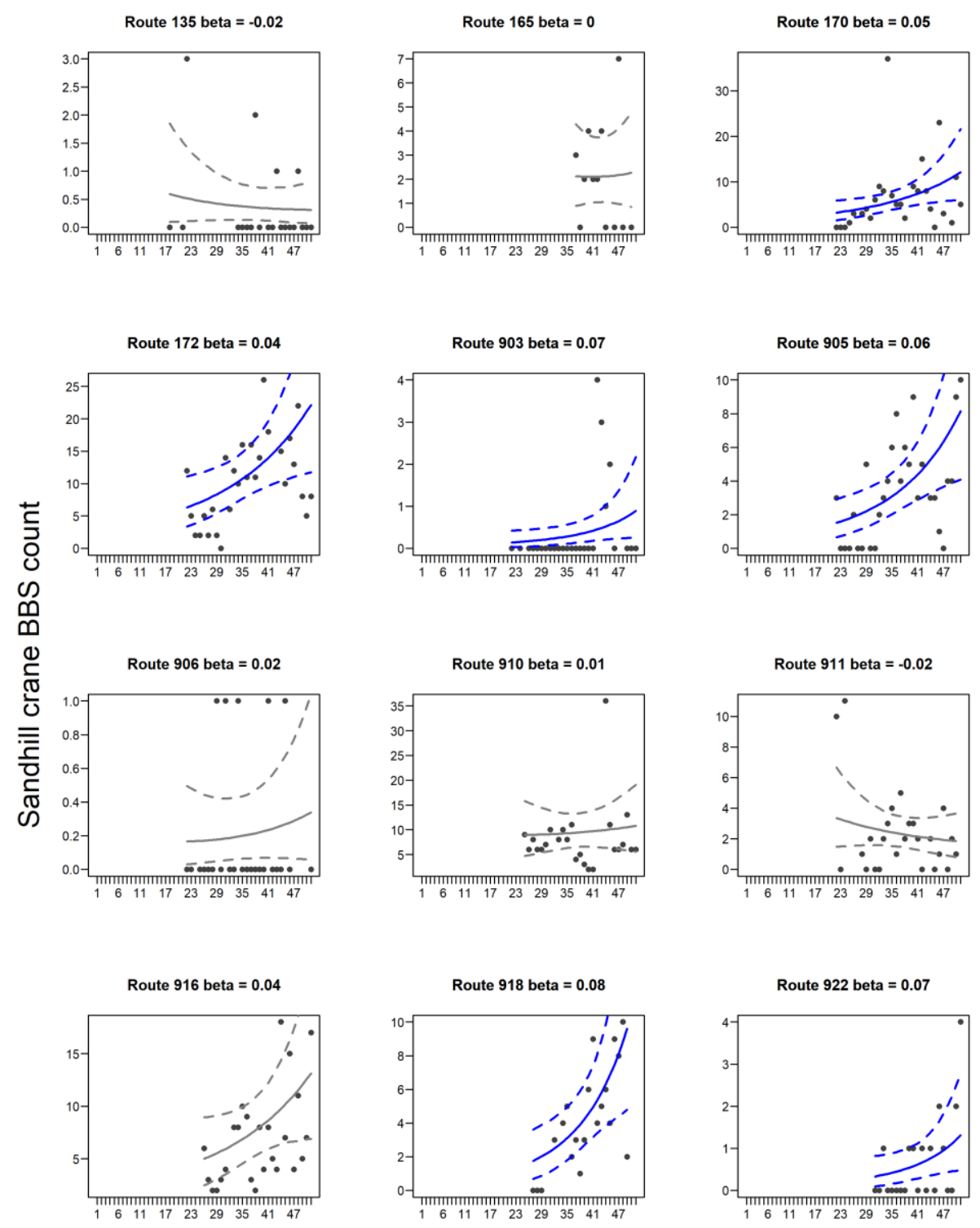